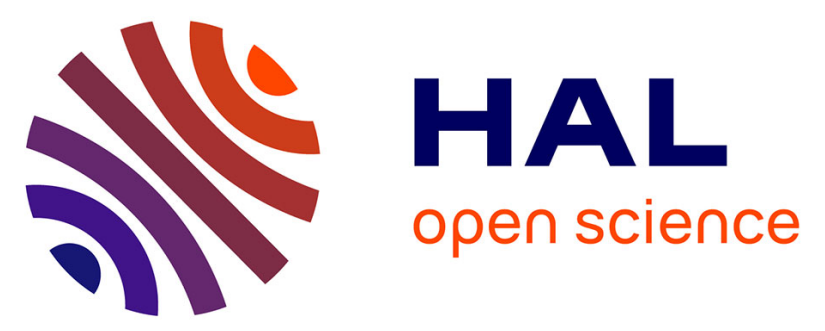

\title{
Acetic Anhydride as an Oxygen Donor in the Non-Hydrolytic Sol-Gel Synthesis of Mesoporous TiO 2 with High Electrochemical Lithium Storage Performances
}

Yanhui Wang, Sanghoon Kim, Nicolas Louvain, Johan Alauzun, P. Hubert Mutin

\section{To cite this version:}

Yanhui Wang, Sanghoon Kim, Nicolas Louvain, Johan Alauzun, P. Hubert Mutin. Acetic Anhydride as an Oxygen Donor in the Non-Hydrolytic Sol-Gel Synthesis of Mesoporous TiO 2 with High Electrochemical Lithium Storage Performances. Chemistry - A European Journal, 2019, 10.1002/chem.201806073 . hal-02073267

\section{HAL Id: hal-02073267 https://hal.science/hal-02073267}

Submitted on 24 Nov 2020

HAL is a multi-disciplinary open access archive for the deposit and dissemination of scientific research documents, whether they are published or not. The documents may come from teaching and research institutions in France or abroad, or from public or private research centers.
L'archive ouverte pluridisciplinaire HAL, est destinée au dépôt et à la diffusion de documents scientifiques de niveau recherche, publiés ou non, émanant des établissements d'enseignement et de recherche français ou étrangers, des laboratoires publics ou privés. 
Acetic anhydride as oxygen donor in the non-hydrolytic sol-gel synthesis of mesoporous $\mathrm{TiO}_{2}$ with high electrochemical lithium storage performances

\author{
Yanhui Wang ${ }^{a}$, Sanghoon Kimª, Nicolas Louvain ${ }^{a, b}$, Johan G. Alauzuna, and P. Hubert Mutin*a
}

An original, halide-free non-hydrolytic sol-gel route to mesoporous anatase $\mathrm{TiO}_{2}$ with hierarchical porosity and high specific surface area is reported. This route is based on the reaction at $200{ }^{\circ} \mathrm{C}$ of titanium (IV) isopropoxide with acetic anhydride, in the absence of a catalyst or of a solvent. NMR studies indicated that this method provides an efficient, truly non-hydrolytic and aprotic route to $\mathrm{TiO}_{2}$. Formation of the oxide involves acetoxylation and condensation successive reactions, both with ester elimination. The resulting $\mathrm{TiO}_{2}$ materials were nanocrystalline, even before calcination. Small $(\approx 10 \mathrm{~nm})$ anatase nanocrystals spontaneously aggregated to form mesoporous micron sized particles with high specific surface area ( $260 \mathrm{~m}^{2} \mathrm{~g}^{-1}$ before calcination). Evaluation of the lithium storage performances showed a high reversible specific capacity, particularly for the non-calcined sample with the highest specific surface area favoring pseudo-capacitive storage: $253 \mathrm{mAh} \mathrm{g}^{-1}$ at $0.1 \mathrm{C}$ and $218 \mathrm{mAh} \mathrm{g}^{-1}$ at $1 \mathrm{C}$ (C $=336 \mathrm{~mA} \mathrm{~g}^{-1}$ ). This sample also showed good cyclability ( $>92 \%$ retention after 200 cycles at $336 \mathrm{~mA} \mathrm{~g}^{-}$ $\left.{ }^{1}\right)$ with a high coulombic efficiency ( $99.8 \%$ ). Synthesis in the presence of a solvent (toluene or squalane) offers the possibility to tune the morphology and texture of the $\mathrm{TiO}_{2}$ nanomaterials.

\title{
Introduction
}

Nanostructured, mesoporous metal oxides are in high demand for advanced applications such as energy storage, photovoltaic conversion, (photo)catalysis or sensing. Due to its outstanding electronic and optical properties, high chemical stability, low toxicity and low cost, nanostructured titanium dioxide is one of the most studied oxide nanomaterials in all of these fields. ${ }^{[1,2]}$ In particular, mesoporous anatase $\mathrm{TiO}_{2}$ is a promising anode material for Li-ion batteries owing to its good capacity, cyclability and safety. ${ }^{[3-5]}$ The elaboration of advanced nanostructured materials depends on the development of powerful synthetic methodologies. The sol-gel process is the most common method used to synthesize mesoporous oxides, as it offers the possibility to obtain metastable phases, with control over composition, homogeneity, and texture. Conventional sol-gel based on hydrolysis and condensation reactions naturally predominates, but non-hydrolytic (or non-aqueous) sol-gel (NHSG) chemistry has been found to provide simple and powerful alternative routes notably for the synthesis of mixed oxides, of nanoparticles, and of mesoporous materials. ${ }^{[6-11]}$

Among the various NHSG routes described in the literature, two main routes have proven particularly successful: i) the so-called benzyl alcohol route, based on the reaction of metal chloride or alkoxide precursors with benzyl alcohol acting as solvent and oxygen donor ${ }^{[12,13]}$ and ii) the alkyl halide elimination route, based on the reaction of metal or silicon chlorides with alkoxide or ether oxygen donors. The benzyl alcohol route has been used mainly in the preparation of crystalline metal oxide nanoparticles, ${ }^{[7,14]}$ while the alkyl halide elimination route has been used both for the preparation of oxide nanoparticles (in the presence of capping agents ${ }^{[15,16]}$ or in dilute conditions ${ }^{[17,18]}$ ) and for the synthesis of non-ordered mesoporous oxides or mixed oxides. ${ }^{[19,20]}$

Ester elimination between acetate and alkoxide precursors (equation 1) is one of the early routes proposed in NHSG. 


$$
\begin{aligned}
& \mathrm{M}(\mathrm{OR})_{4}+\mathrm{M}^{\prime}(\mathrm{OAc})_{4} \longrightarrow \mathrm{MM}^{\prime} \mathrm{O}_{4-\mathrm{x}}(\mathrm{OR})_{\mathrm{x}}(\mathrm{OAc})_{\mathrm{x}}+4-\mathrm{x} \mathrm{AcOR} \\
& \mathrm{M}=\mathrm{Zr} ; \mathrm{M}^{\prime}=\mathrm{Si}, \mathrm{Zr} ; \mathrm{R}={ }^{\mathrm{n}} \mathrm{Pr}
\end{aligned}
$$

This route appears seducing because it does not involve chloride precursors. However, the only oxide materials prepared by this route were $\mathrm{ZrO}_{2}$ and $\mathrm{SiO}_{2}-\mathrm{ZrO}_{2}{ }^{[21]}$ This limited success was most likely due to the lack of commercially available anhydrous metal acetates. Generating acetoxy groups in situ would be of great interest to widen the scope of the ester elimination route, but the first reaction that comes to mind, the reaction of metal alkoxides with acetic acid, does not afford a non-hydrolytic solgel method as water will form by esterification of acetic acid with the alcohol released (equations 2 and 3). ${ }^{[9,22,23]}$ Water formation can only be avoided in atomic layer deposition methods, where reactants and by-products are flushed after each alternate pulse of metal alkoxide and acetic acid. ${ }^{[24,}$ ${ }^{25]}$ In 1996, Vioux et al. proposed to form acetoxy groups in situ by reaction of acetic anhydride with an alkoxide (equation 4). ${ }^{[26]}$ However, at that time, the reaction was found too slow to be practical and this route remained practically unexplored. Thus, in the case of the reaction of $\mathrm{Ti}\left(\mathrm{O}^{\prime} \mathrm{Pr}\right)_{4}$ with acetic anhydride, no solid formed even after 7 days at $140{ }^{\circ} \mathrm{C}$ in the absence of $\mathrm{TiCl}_{4}$ catalyst. ${ }^{[26]}$ The same reaction catalyzed by $\mathrm{TiCl}_{4}$ was later used by Fox and coworkers to prepare $\mathrm{TiO}_{2}$ nanomaterials in supercritical $\mathrm{CO}_{2}$ at $110{ }^{\circ} \mathrm{C}$, but before calcination only amorphous, poorly condensed powders were obtained. ${ }^{[27]}$

$$
\begin{aligned}
& \mathrm{M}-\mathrm{OR}+\mathrm{CH}_{3} \mathrm{CO}_{2} \mathrm{H} \longrightarrow \mathrm{M}-\mathrm{OCOCH}_{3}+\mathrm{ROH} \\
& \mathrm{ROH}+\mathrm{CH}_{3} \mathrm{CO}_{2} \mathrm{H} \longrightarrow \mathrm{CH}_{3} \mathrm{CO}_{2} \mathrm{R}+\mathrm{H}_{2} \mathrm{O} \\
& \mathrm{M}-\mathrm{OR}+\left(\mathrm{CH}_{3} \mathrm{CO}\right)_{2} \mathrm{O} \longrightarrow \mathrm{M}-\mathrm{OCOCH}_{3}+\mathrm{CH}_{3} \mathrm{COOR}
\end{aligned}
$$

In the present work we revisit the use of acetic anhydride as an oxygen donor. We found that reacting $\mathrm{Ti}\left(\mathrm{O}^{\prime} \mathrm{Pr}\right)_{4}$ with a stoichiometric amount of $\mathrm{Ac}_{2} \mathrm{O}$ at $200{ }^{\circ} \mathrm{C}$, in the absence of a catalyst or a solvent, leads in high yield to mesoporous anatase $\mathrm{TiO}_{2}$. The reactions involved were identified, and the morphology, structure, texture and lithium ion storage performances of this mesoporous $\mathrm{TiO}_{2}$ (before and after calcination) were investigated in details. Mesoporous $\mathrm{TiO}_{2}$ samples were also prepared in the presence of toluene or squalane to study the influence of added solvent.

\section{Results and discussion}

\section{Reactions involved and nature of residual groups}

The first aim of this work was to show that the reaction of a metal alkoxide precursor with acetic anhydride could afford in the absence of a catalyst a valuable route to mesoporous metal oxides. After testing several reaction temperatures, we found that at $200{ }^{\circ} \mathrm{C}$ the reaction of $\mathrm{Ti}(\mathrm{O} \mathrm{Pr})_{4}$ with a stoichiometric amount of acetic anhydride (2 equivalents) led after $12 \mathrm{~h}$ to mesoporous $\mathrm{TiO}_{2}$ in high yields $(\approx 90 \%$ on isolated product after calcination). To elucidate the reaction mechanism, the liquid by-products of the reaction were analyzed by NMR. According to ${ }^{1} \mathrm{H}$ and ${ }^{13} \mathrm{C}$ NMR spectra (Figure $1 \mathrm{a}, \mathrm{b}$ ), the liquid phase contained mainly isopropyl acetate ( $\approx 95 \mathrm{~mol} \%)$. The formation of this major byproduct is consistent with a 2-step mechanism, involving acetoxylation (equation 5 ) and condensation (equation 6) reactions, with in both cases elimination of isopropyl acetate. 


$$
\begin{aligned}
& \mathrm{Ti}-\mathrm{O} \mathrm{Pr}+\left(\mathrm{CH}_{3} \mathrm{CO}\right)_{2} \mathrm{O} \longrightarrow \mathrm{Ti}-\mathrm{OCOCH}_{3}+\mathrm{CH}_{3} \mathrm{COO}^{\mathrm{i}} \mathrm{Pr} \\
& \mathrm{Ti-O} \mathrm{Pr}+\mathrm{Ti}-\mathrm{OCOCH}_{3} \longrightarrow \mathrm{Ti}-\mathrm{O}-\mathrm{Ti}+\mathrm{CH}_{3} \mathrm{COO}^{\mathrm{i}} \mathrm{Pr}
\end{aligned}
$$

A small amount of acetic acid $(\approx 5 \mathrm{~mol} \%)$ was also detected, possibly resulting from hydrolysis reactions during the isolation of the by-products. It is noteworthy that neither propylene, isopropanol nor water were detected, indicating that thermal decomposition of titanium isopropoxide ${ }^{[28]}$ followed by condensation of the resulting Ti-OH groups was negligible under our conditions (Scheme S1 in ESI).
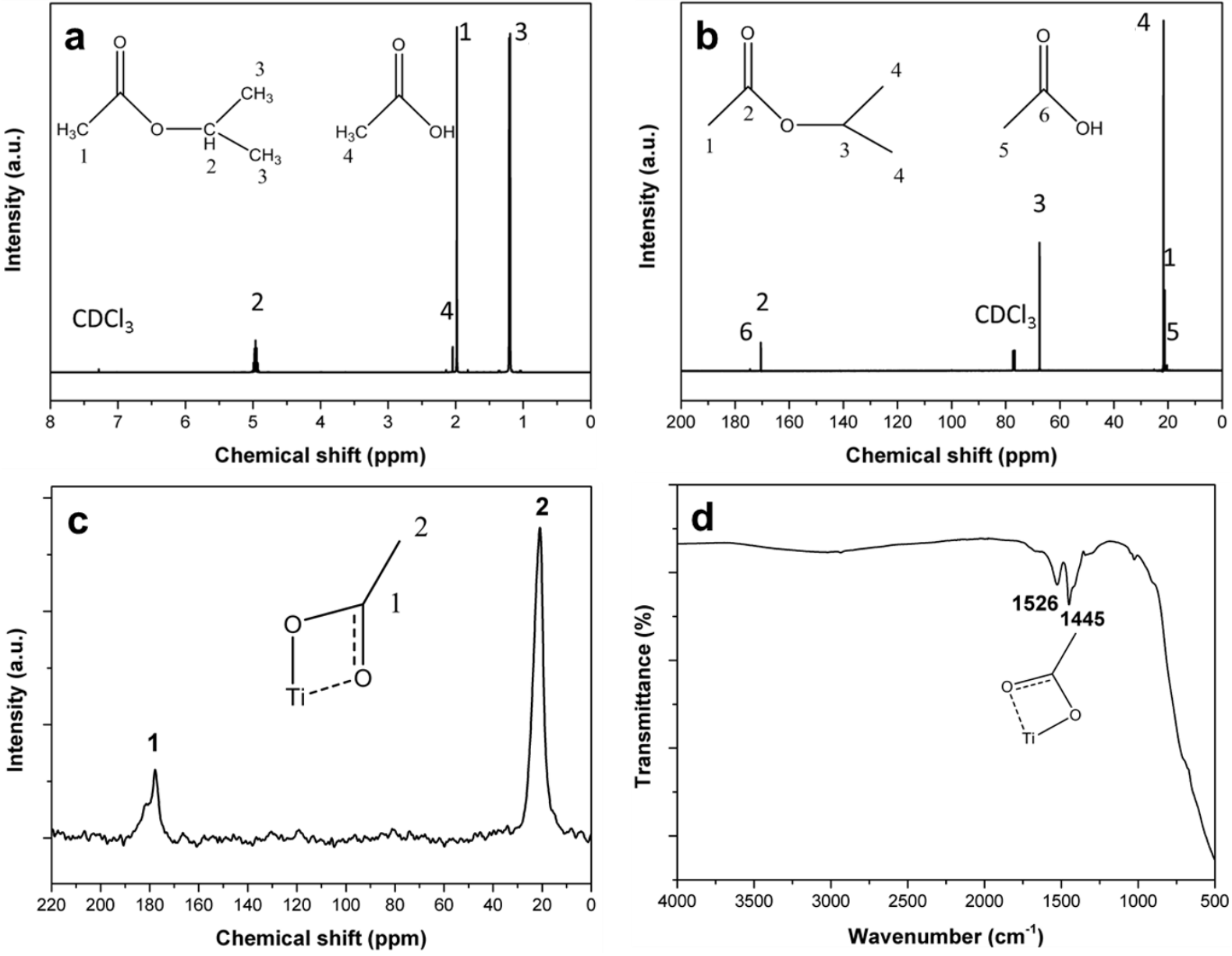

Figure 1. a) ${ }^{1} \mathrm{H}$ NMR and b) ${ }^{13} \mathrm{C}$ NMR spectra in $\mathrm{CDCl}_{3}$ of the liquid by-products after reaction of $\mathrm{Ti}\left(\mathrm{O}^{\mathrm{O}} \mathrm{Pr}\right)_{4}$ with $\mathrm{Ac}_{2} \mathrm{O}$ (no solvent) at $200^{\circ} \mathrm{C}$ for $12 \mathrm{~h}$; c) solid-state ${ }^{13} \mathrm{C}$ CPMAS-NMR and d) ATR-FTIR spectra of $\mathrm{TiO}_{2^{-}}$ NS-nc.

Both ${ }^{13} \mathrm{C}$ CPMAS NMR and FTIR spectroscopies of the solid xerogel showed the presence of residual acetoxy groups, consistent with this non-hydrolytic mechanism (Figure $1 \mathrm{c}, \mathrm{d}$ ). The solid state ${ }^{13} \mathrm{C} N \mathrm{NM}$ spectrum of the washed and dried $\mathrm{TiO}_{2}$-NS-nc powder displayed resonances at 20 and $180 \mathrm{ppm}$, ascribed to the methyl and carboxylate groups, respectively. The ATR-FTIR spectrum displayed two strong absorption bands at $1445 \mathrm{~cm}^{-1}$ and $1526 \mathrm{~cm}^{-1}$ attributed to the symmetric and asymmetric stretching vibration of surface carboxylate groups, respectively. The separation of the two bands $\left(\Delta v=81 \mathrm{~cm}^{-1}\right)$ suggests that these carboxylate groups are in a bidentate chelating mode. ${ }^{[22]}$ The broad absorption around $3400 \mathrm{~cm}^{-1}$ characteristic of $\mathrm{O}-\mathrm{H}$ stretching vibrations is comparatively very weak, indicating a very low amount of surface hydroxyl groups or adsorbed water, possibly resulting from the hydrolysis of residual surface groups during washing or manipulations in air. A very weak vibration 
at $2937 \mathrm{~cm}^{-1}$ (barely visible in figure $1 \mathrm{~d}$ ) is ascribed to $\mathrm{C}-\mathrm{H}$ stretching vibrations, possibly in $\mathrm{CH}_{3}$ groups of residual acetoxy groups.

Thermogravimetric analysis of $\mathrm{TiO}_{2}$-NS-nc in air (Figure S1 in ESI) indicated a $9 \%$ weight loss at $800{ }^{\circ} \mathrm{C}$. Assuming the presence of residual acetoxy groups only, this weight loss would correspond to a degree of condensation of $96 \%$ (conversion of $\mathrm{TiO}_{1.92}(\mathrm{OAc})_{0.16}$ into $\mathrm{TiO}_{2}$ ). Accordingly, the reaction of titanium isopropoxide with acetic anhydride at $200{ }^{\circ} \mathrm{C}$ provides an efficient, truly non-hydrolytic route to titanium dioxide with a very high condensation degree.

\section{Characterization}
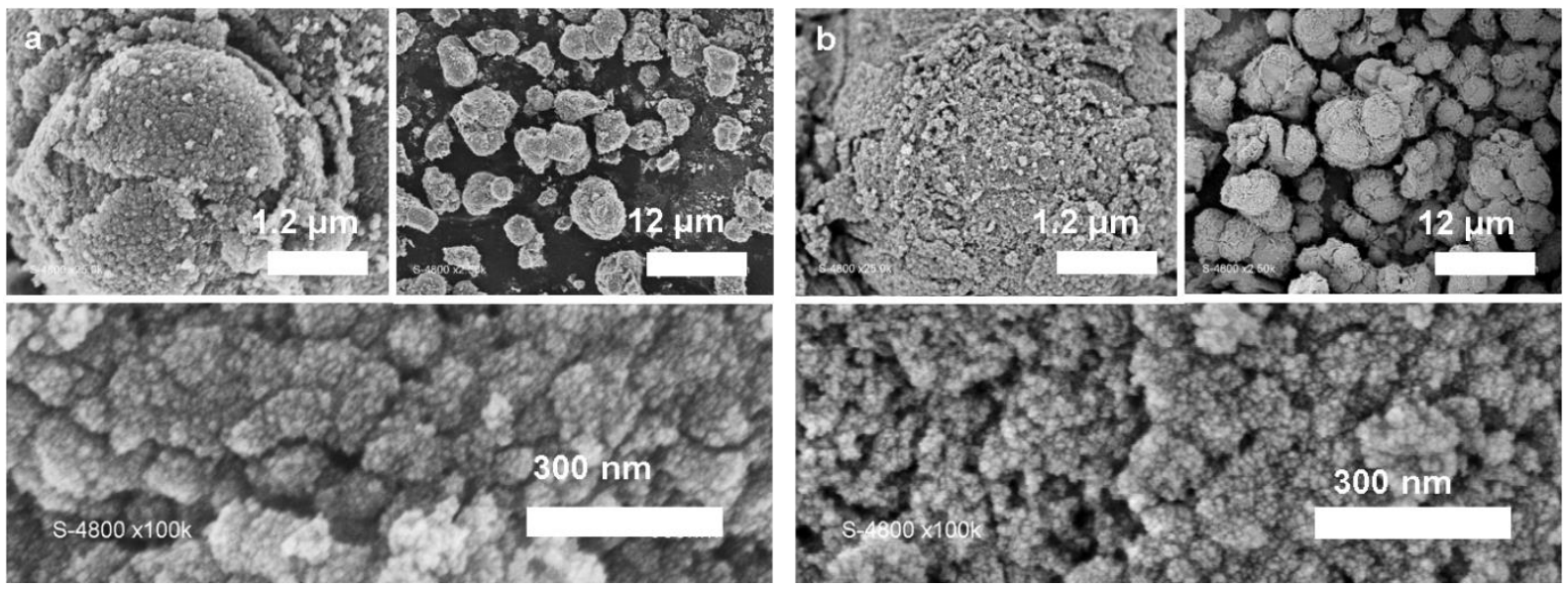

Figure 2. SEM images of a) non-calcined and b) calcined $\mathrm{TiO}_{2}$-NS samples.

Representative SEM images of the $\mathrm{TiO}_{2}$-NS samples before and after calcination are displayed in Figure 2. As shown by these images, the morphology of the samples was not affected by the calcination treatment. Both $\mathrm{TiO}_{2}-\mathrm{NS}-\mathrm{nc}$ and $\mathrm{TiO}_{2}$-NS-c samples showed an interesting hierarchical morphology: small rounded primary nanoparticles with diameters of $\approx 10 \mathrm{~nm}$ self-assembled to form spherical secondary particles with diameters of about 3 to $6 \mu \mathrm{m}$.

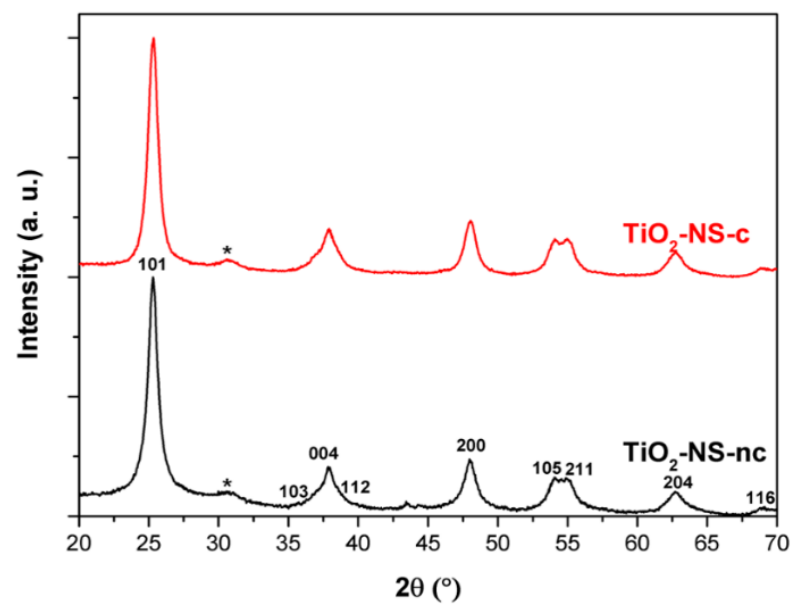

Figure 3. Powder XRD patterns of non-calcined and calcined $\mathrm{TiO}_{2}$-NS samples. The reflection marked by an asterisk arises from traces of brookite) 
The XRD patterns of the $\mathrm{TiO}_{2}$-NS powders (Figure 3) showed the presence of anatase nanocrystals mainly (JCPDS 21-1272), along with traces of brookite (JCPDS 29-1360) evidenced by the low-intensity peak at $30.8^{\circ}$. The crystallite size, estimated from the Scherrer equation for the (101) reflection, increased slightly from 9.5 to $10.5 \mathrm{~nm}$ upon calcination, indicating limited grain growth. These sizes are similar to the sizes observed by SEM (Figure 2) or HR-TEM (Figure 4), showing that the primary nanoparticles in SEM images were anatase nanocrystals.

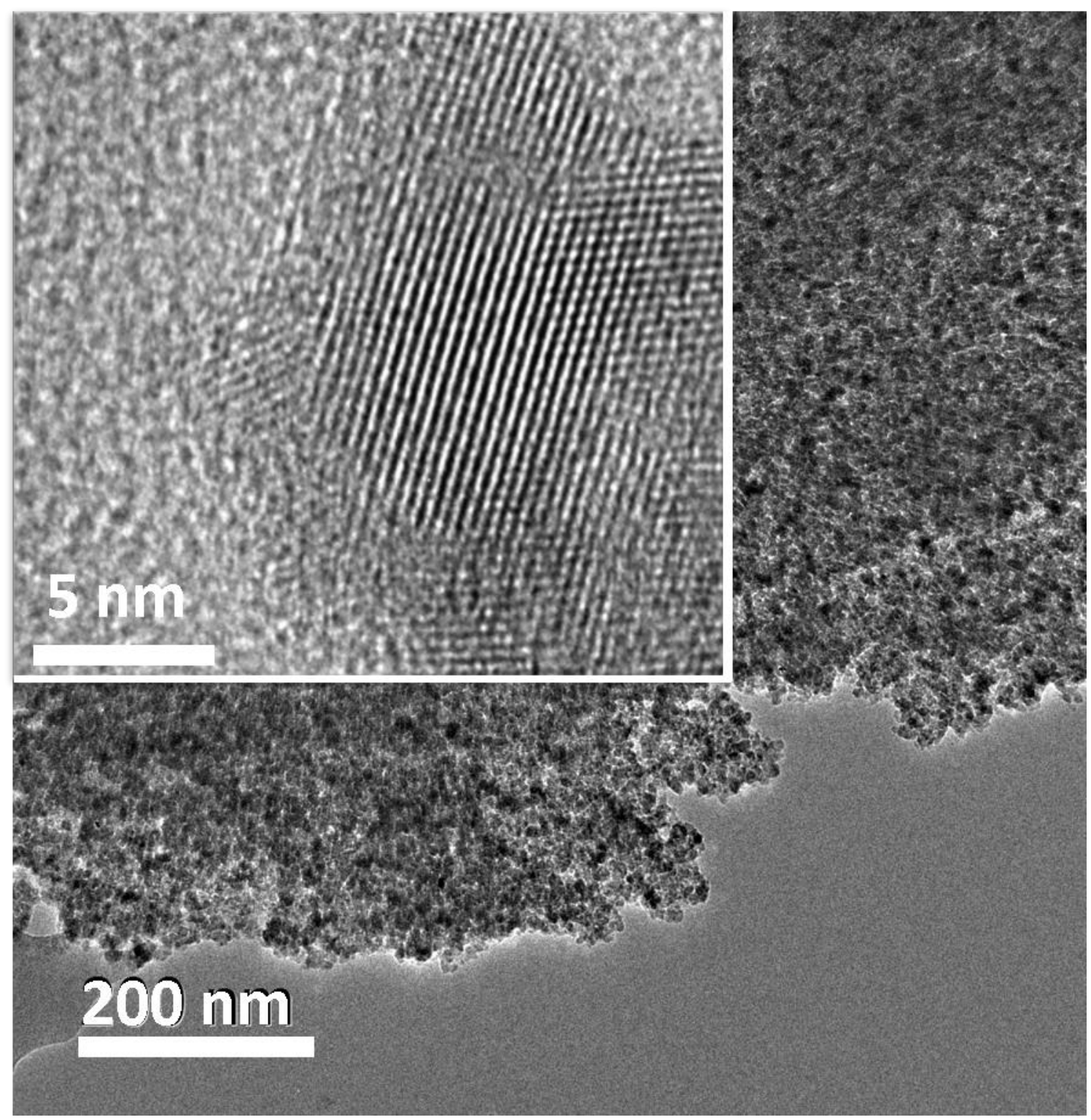

Figure 4. HRTEM images of $\mathrm{TiO}_{2}-\mathrm{NS}-\mathrm{c}$. 

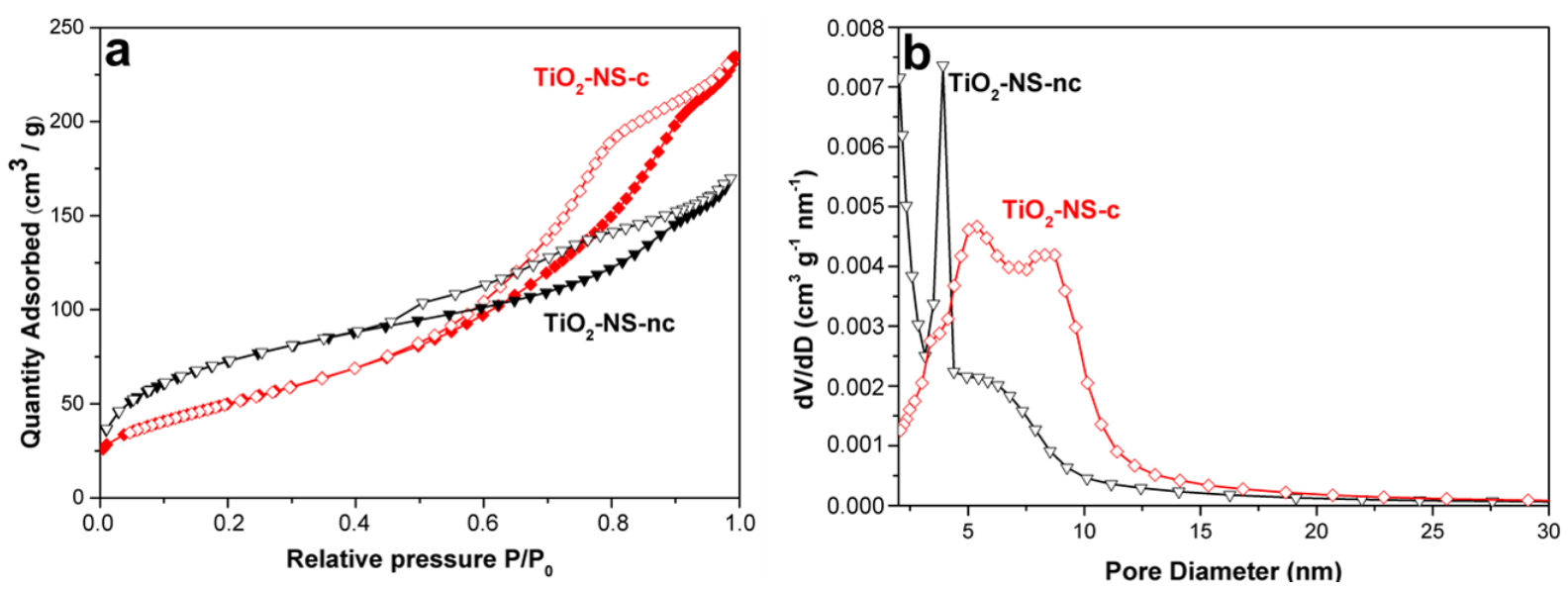

Figure 5. a) $\mathrm{N}_{2}$ physisorption isotherms at $77 \mathrm{~K}$ and b) $\mathrm{BJH}$ mesopore size distribution of non-calcined and calcined $\mathrm{TiO}_{2}$-NS samples. The filled and open symbols refer to adsorption and desorption, respectively

The nitrogen physisorption isotherms of $\mathrm{TiO}_{2}-\mathrm{NS}$ samples before and after calcination are reported in Figure 5a. Composite Type IVa + Type II isotherms are observed, indicating the presence of mesopores between the primary particles and of macropores between the micronic spherical aggregates. ${ }^{[29]}$ Similar isotherms have been reported for hierarchically mesoporous anatase spheres prepared using a $\mathrm{TiO}_{2}-\mathrm{CdSO}_{4}$ composite as intermediate. ${ }^{[30]} \mathrm{BJH}$ analysis (Figure 5b) or DFT (Figure S2) confirmed the presence of mesopores with a broad pore size distribution. The BET specific surface area of the noncalcined $\mathrm{TiO}_{2}$-NS sample was $260 \mathrm{~m}^{2} \mathrm{~g}^{-1}$, which is very high for a crystalline $\mathrm{TiO}_{2}$ material. For comparison, mesoporous $\mathrm{TiO}_{2}$ materials prepared by conventional sol-gel are usually amorphous before calcination, and when crystalline their specific surface areas are usually below $150 \mathrm{~m}^{2} \mathrm{~g}^{-1}$. [31] Specific surface area of more than $300 \mathrm{~m}^{2} \mathrm{~g}^{-1}$ have already been reported for $\mathrm{TiO}_{2}$ materials, but these materials were prepared either by elaborated hydrolytic sol-gel protocols ${ }^{[32,33]}$ or by non-hydrolytic sol-gel in dilute conditions from $\mathrm{TiCl}_{4}$ and benzyl alcohol ${ }^{[12]}$ or from $\mathrm{TiCl}_{4}$ and diisopropyl ether. ${ }^{[18]}$ Calcination of $\mathrm{TiO}_{2}$-NS-nc led to a decrease of the specific surface area from 260 to $190 \mathrm{~m}^{2} \mathrm{~g}^{-1}$ and to an increase of the average pore diameter from 4.1 to $7.7 \mathrm{~nm}$, suggesting that some sintering of the primary nanoparticles took place.

\section{Electrochemical performance}



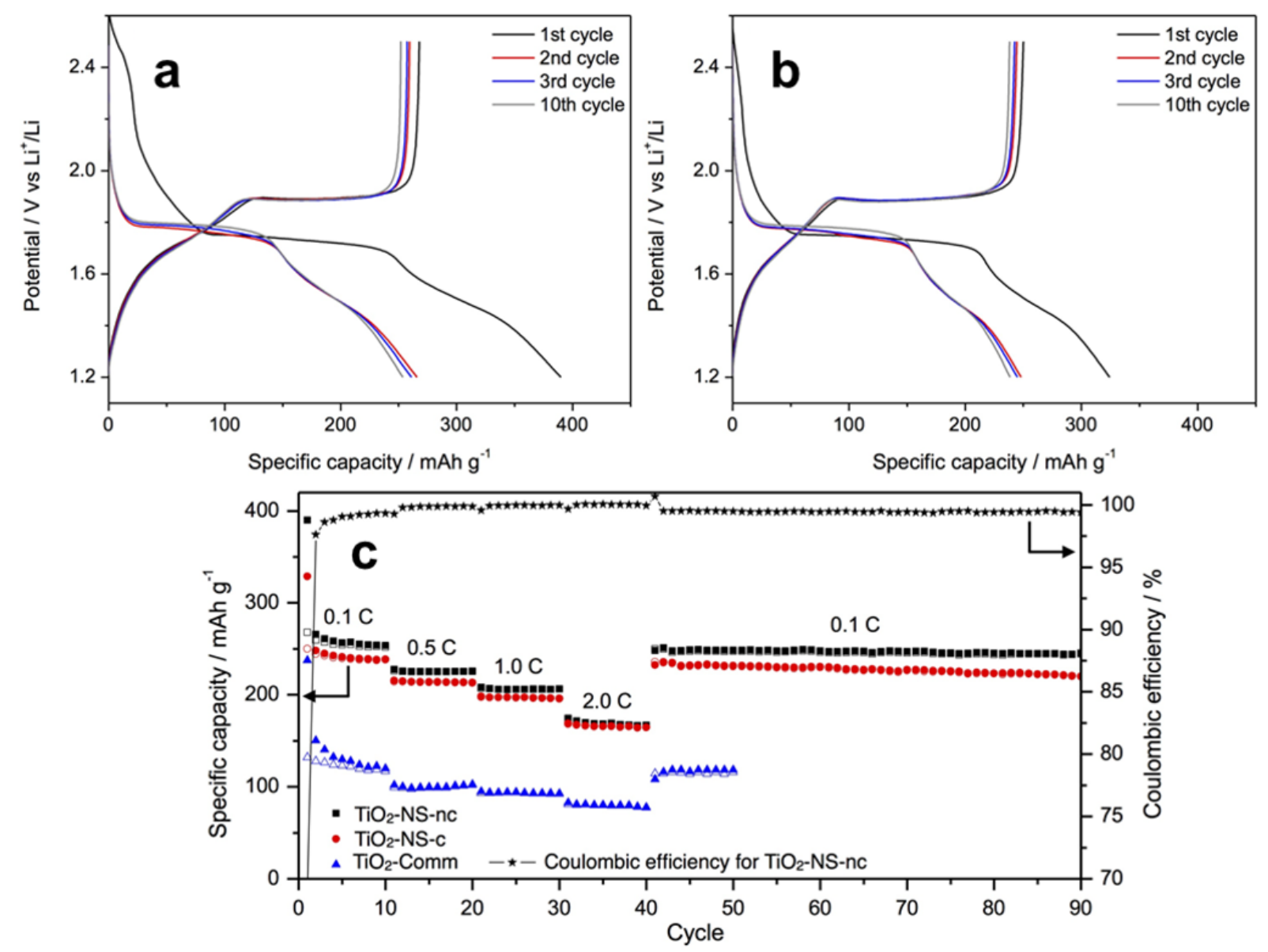

Figure 6. Galvanostatic charge-discharge voltage profiles at $\mathrm{C} / 10$ between 1.2 and $2.5 \mathrm{~V}$ of a) $\mathrm{TiO}_{2}-\mathrm{NS}-$ $\mathrm{nc}$, b) $\mathrm{TiO}_{2}-\mathrm{NS}-\mathrm{c}$;. c) Rate capability and long term cyclability test. Filled and open symbols refer to reduction (discharge) and oxidation (charge), respectively, $\mathrm{C}=336 \mathrm{~mA} \mathrm{~g}^{-1}$.

The electrochemical lithium storage performance of the $\mathrm{TiO}_{2}$-NS samples was investigated by galvanostatic cycling in a half-cell configuration and compared to that of a commercial $\mathrm{TiO}_{2}$ sample ( $\mathrm{TiO}_{2}$-Comm, anatase, $85 \mathrm{~m}^{2} \mathrm{~g}^{-1}$, see Experimental Section). Figures $6 \mathrm{a}$ and $6 \mathrm{~b}$ show galvanostatic charge-discharge voltage profiles of the non-calcined and calcined samples, respectively. The discharge profiles show the three distinct regions characteristic of anatase $\mathrm{TiO}_{2}$ cycled versus lithium. ${ }^{[5}$, ${ }^{31]}$ In region I the initial fast potential drop to $1.8 \mathrm{~V}$ is ascribed to the formation of a $\mathrm{Li}_{\varepsilon} \mathrm{TiO}_{2}$ solidsolution. In region II the constant voltage plateau at approxiamtely $1.8 \mathrm{~V}$ corresponds to the two-phase region where lithium-poor $\left(\mathrm{Li}_{0.05} \mathrm{TiO}_{2}\right)$ and lithium-rich $\left(\mathrm{Li}_{0.5} \mathrm{TiO}_{2}\right)$ solid solutions coexist. In region III, the sloped curve below $1.7 \mathrm{~V}$ is attributed to reversible surface lithium storage.

Interestingly, the presence of organic residual groups in $\mathrm{TiO}_{2}-\mathrm{NS}-\mathrm{nc}$ did not hamper electrochemical cycling, even at high C-rates (Figure $6 \mathrm{c}$ ). Although $\mathrm{TiO}_{2}-\mathrm{NS}$-nc contained $\approx 9 \mathrm{wt} \%$ of organics its specific capacity was higher than that of $\mathrm{TiO}_{2}$ - NS-c. The specific capacities at $0.1 \mathrm{C}$ on the $10^{\text {th }}$ discharge curve were very high: $253 \mathrm{mAh} \mathrm{g}^{-1}$ for $\mathrm{TiO}_{2}-\mathrm{NS}-\mathrm{nc}$ and $238 \mathrm{mAh} \mathrm{g}^{-1}$ for $\mathrm{TiO}_{2}$-NS-c. These values are nearly twice higher than that found for $\mathrm{TiO}_{2}-\mathrm{Comm}\left(119 \mathrm{mAh} \mathrm{g}^{-1}\right)$ (Figure S3 in $\mathrm{SI}$ ), and they compare well with

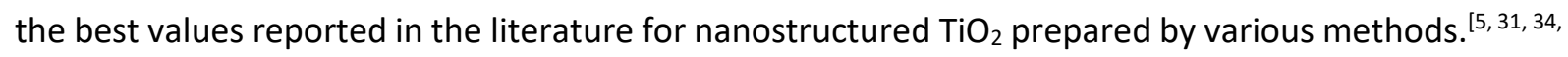
${ }^{35]}$ The specific capacity arising from reversible surface lithium storage in Region III can be estimated to be $115 \mathrm{mAh} \mathrm{g}^{-1}$ and $95 \mathrm{mAh} \mathrm{g}^{-1}$ for $\mathrm{TiO}_{2}-\mathrm{NS}-\mathrm{nc}$ and $\mathrm{TiO}_{2}-\mathrm{NS}-\mathrm{C}$, respectively, compared to $30 \mathrm{mAh} \mathrm{g}^{-1}$ for $\mathrm{TiO}_{2}$-Comm. Accordingly, the differences in specific capacity between $\mathrm{TiO}_{2}-\mathrm{NS}-\mathrm{nc}, \mathrm{TiO}_{2}-\mathrm{NS}-\mathrm{c}$, and $\mathrm{TiO}_{2}-$ 
Comm are mostly related to surface lithium storage, which depends on the specific surface area of the materials. ${ }^{[31,36]}$ The acetate groups of $\mathrm{TiO}_{2}$-NS-nc were possibly exchanged or decomposed during the $1^{\text {st }}$ discharge as suggested by the shoulder in the galvanostatic curve (indicated by an arrow in Figure 6a). As a result, the initial coulombic efficiency of $\mathrm{TiO}_{2}-\mathrm{NS}$-nc was slightly lower than that of $\mathrm{TiO}_{2}-\mathrm{NS}-\mathrm{C}$ (70.0 \% vs $76.1 \%$ ). In the subsequent cycles, however, both $\mathrm{TiO}_{2}$-NS samples showed an excellent coulombic efficiency (>99.7\%). It is noteworthy that after cycling at higher rates, both $\mathrm{TiO}_{2}$ samples recovered their initial capacity at $0.1 \mathrm{C}$, meaning that these $\mathrm{TiO}_{2}$ materials were not significantly degraded. The long term cyclability of $\mathrm{TiO}_{2}$-NS-nc was particularly good: its capacity remained constant over 50 cycles at $0.1 \mathrm{C}$, while a slight continuous capacity decrease was observed for $\mathrm{TiO}_{2}$-NS-c (Figure $6 \mathrm{c})$. As shown in Figure $\mathrm{S4}, \mathrm{TiO}_{2}$-NS-nc was also stable at higher rate (1C) with a discharge capacity of $201 \mathrm{mAh} \mathrm{g}^{-1}$ after 200 cycles (corresponding to $92 \%$ capacity retention) and a coulombic efficiency of $99.8 \%$.

$\mathrm{TiO}_{2}$-NS-nc and $\mathrm{TiO}_{2}$-NS-c samples were further analyzed by electrochemical impedance spectroscopy (EIS) and cyclic voltammetry (Figure 7). The Nyquist plots of both $\mathrm{TiO}_{2}$ samples (Figure 7a,b) displayed an arc in the middle- to high- frequency range, corresponding to the charge-transfer resistance $\left(R_{c t}\right)$ and solid electrolyte interphase resistance $\left(\mathrm{R}_{\mathrm{SE}}\right)$, and an angled line in the low-frequency region corresponding to the lithium diffusion in the electrode. ${ }^{[37]}$ The semicircles for the non-calcined samples were similar whatever the number of cycles, and smaller than those for the calcined sample, particularly for the first cycles. Simulation of the Nyquist plots after the $10^{\text {th }}$ cycle using an equivalent model circuit (Figure S5) showed that both $\mathrm{R}_{\mathrm{ct}}$ and $\mathrm{R}_{\mathrm{SEl}}$ values were significantly smaller for $\mathrm{TiO}_{2}$-NS-nc $\left(R_{c t}=17.4 \Omega\right.$ and $\left.R_{S E I}=11.4 \Omega\right)$ than for $\mathrm{TiO}_{2}-N S-c\left(R_{c t}=23.8 \Omega\right.$ and $\left.R_{S E I}=21.7 \Omega\right)$. This suggests that the residual acetate groups and their decomposition products not only did not hamper electrochemical cycling but could also improve electrochemical performance, probably because the SEl formation could be different from that of $\mathrm{TiO}_{2}$-Ns-c. 

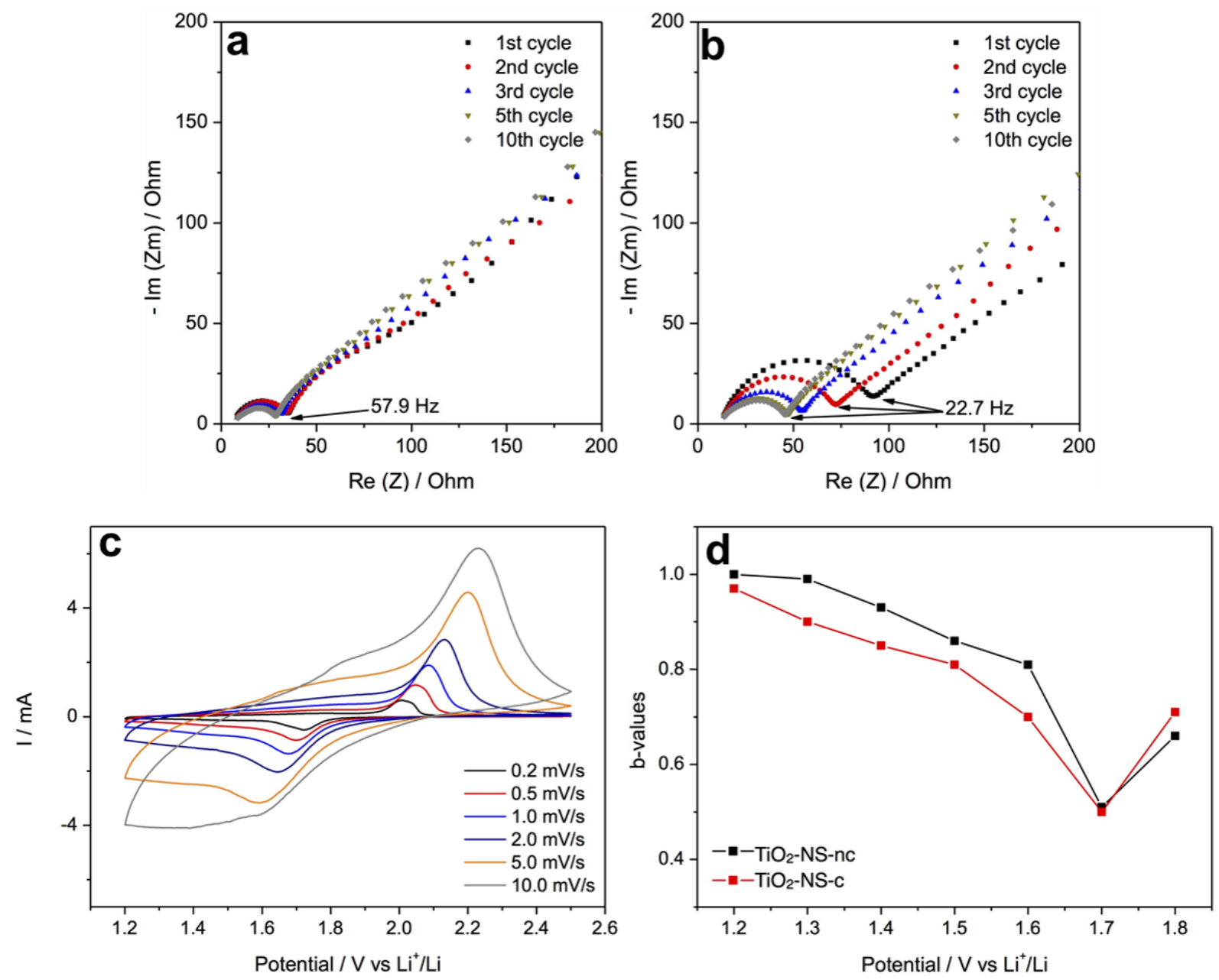

Figure 7. a) Nyquist plots obtained at discharged state of a) $\mathrm{TiO}_{2}-\mathrm{NS}-\mathrm{nc}$ and b) $\mathrm{TiO}_{2}-\mathrm{Ns}-\mathrm{c}$ cycled at $0.1 \mathrm{C}$ $\left.\left(33.6 \mathrm{~mA} \mathrm{~g}^{-1}\right), \mathrm{c}\right)$ cyclic voltammetry curves of $\mathrm{TiO}_{2}$-NS-nc at various scan rates, d) Calculated $b$-values for $\mathrm{TiO}_{2}$-NS-nc and $\mathrm{TiO}_{2}$-NS-c as a function of the potential for cathodic sweeps (lithium insertion).

Cyclic voltammetry was performed at different sweep rates (Figure 7c). In $\mathrm{TiO}_{2}$ anatase nanomaterials, pseudo-capacitive storage can become important when the nanoparticle size decreases. ${ }^{[38,}{ }^{39]}$ The relative contributions of capacitive and intercalation behavior was evaluated by analysis of cyclic voltammetry curves from 1.2 to $1.8 \mathrm{~V}$ according to:

$$
i=a v^{b}
$$

where $i$ stands for measured current, $v$ for sweep rate and $a, b$ are adjustable parameters. For a lithium intercalation mechanism $b=0.5$, while for a a purely capacitive mechanism $b=1.0 .{ }^{[40,41]}$ As can be seen in Figure $7 \mathrm{~d}$, at the peak potential of $1.7 \mathrm{~V}, b$-values for both $\mathrm{TiO}_{2}$-NS samples are very close to 0.5 indicating that the current results mainly from lithium intercalation reactions (plateau in the galvanostatic curve in Figure 6a-b). Conversely, below $1.7 \mathrm{~V} b$-values increase, indicating that the capacitive mechanism becomes more and more important, and predominates below 1.6 V. Between 1.2 and $1.6 \mathrm{~V}$ the $b$-values found for $\mathrm{TiO}_{2}-\mathrm{NS}$-nc are higher than those found for $\mathrm{TiO}_{2}-\mathrm{NS}$-c, indicating a larger contribution of capacitive storage for $\mathrm{TiO}_{2}-\mathrm{NS}-\mathrm{nc}$, most likely due to its higher specific surface area. 


\section{Influence of the addition of a solvent}

Although the possibility to prepare $\mathrm{TiO}_{2}$ materials in the absence of solvent is a major advantage of our acetic anhydride route, additional experiments were done to investigate the influence a solvent (namely toluene or squalane) on the characteristics of the materials.
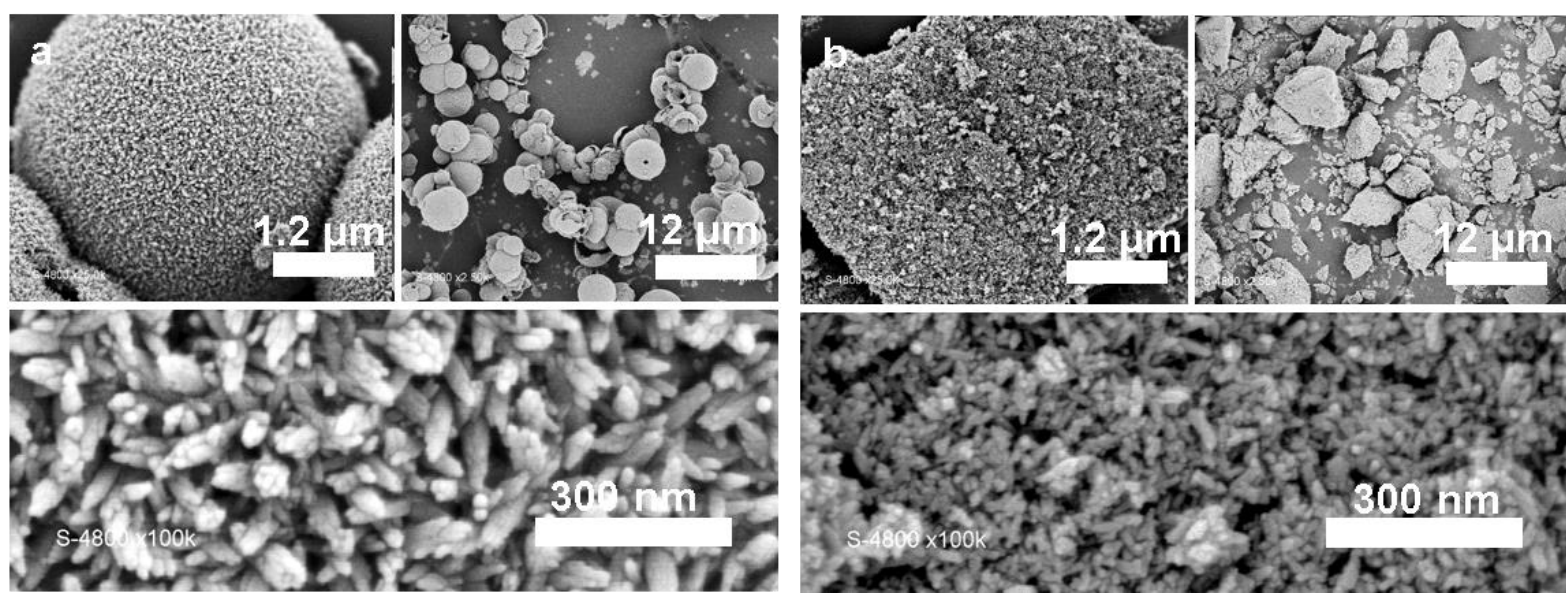

Figure 8. SEM images of calcined $\mathrm{TiO}_{2}$ samples produced from $\mathrm{Ti}\left(\mathrm{O}^{\mathrm{i}} \mathrm{Pr}\right)_{4}$ and $\mathrm{Ac}_{2} \mathrm{O}$ at $200{ }^{\circ} \mathrm{C}$ a) in squalane $\left(\mathrm{TiO}_{2}-\mathrm{Squ}-\mathrm{c}\right)$ and $\left.\mathrm{b}\right)$ in toluene $\left(\mathrm{TiO}_{2}-\mathrm{Tol}-\mathrm{c}\right)$.

As shown by the SEM images in Figure 8 and S6, the morphology of the samples strongly depended on the presence of a solvent and on its nature. The $\mathrm{TiO}_{2}$ sample prepared in toluene consisted of shapeless aggregates built of short nanorods up to $\approx 40 \mathrm{~nm}$ in length. According to HR-TEM images (Figure S7), these nanorods were well-crystallized, with diameters of $\approx 6-7 \mathrm{~nm}$. The sample prepared in squalane showed an interesting hierarchical morphology: short nanorods were assembled to form spindles, which themselves further aggregated to build spiky spheres, about 2.5 to $5 \mu \mathrm{m}$ in diameter. Images of broken spheres indicated that they were hollow. The XRD patterns of the $\mathrm{TiO}_{2}$-Tol-nc and $\mathrm{TiO}_{2}$-Squ-nc samples (Figure S8) showed the presence of anatase nanocrystals, with sizes $\approx 10 \mathrm{~nm}$ which increased slightly upon calcination to $\approx 11 \mathrm{~nm}$ (Table 1). The higher intensity of the (004) reflection compared to the (200) reflection is consistent with the nanorod morphology observed by SEM for these samples. ${ }^{[23,}$

${ }^{42]}$ It is well known in nanoparticle synthesis that both the morphology of the particles can be tuned by the addition of small amounts of ligands or by changing synthesis conditions. In our case, the impact of the solvent on the morphology could arise from preferential adsorption of solvent molecules (or of impurities in the solvent) during crystal growth. Another possibility would be that the solvent favors oriented attachment of anatase crystallites. ${ }^{[43]}$ Unfortunately, as already noted for the non-hydrolytic synthesis of nanocrystalline metal oxides by the benzyl alcohol route, ${ }^{[8]}$ the role of the organic species during the growth of the inorganic nanoparticles is not well understood. Thus, playing on the reaction conditions offers us the possibility to tune the morphology of our samples, but predicting this morphology is not yet possible.

The texture of the $\mathrm{TiO}_{2}$ samples is also impacted by the use of a solvent (Figure S9-S10). The physisorption isotherms of the samples prepared in toluene were of type IVa, characteristic of mesoporous adsorbents, while for the samples prepared in squalane, composite Type IVa + Type II isotherms were observed, indicating the presence of mesopores between the primary particles and of macropores between the spherical aggregates. The textural data for the different $\mathrm{TiO}_{2}$ samples 
prepared in this work are compared in Table 1. The specific surface areas of the samples prepared in the presence of a solvent were similar ( $\approx 170 \mathrm{~m}^{2} \mathrm{~g}^{-1}$ before calcination, $\approx 120 \mathrm{~m}^{2} \mathrm{~g}^{-1}$ after calcination), significantly lower than those of the samples prepared without solvent.

Table 1. Comparison of anatase crystallite size and textural data for the different $\mathrm{TiO}_{2}$ samples, before and after calcination.

\begin{tabular}{ccccc}
\hline Sample & $\begin{array}{c}\text { Cryst. } \\
\text { size }(\mathrm{nm})\end{array}$ & $\begin{array}{c}\mathrm{S}_{\mathrm{BET}}{ }^{\mathrm{b}} \\
\left(\mathrm{m}^{2} \mathrm{~g}^{-1}\right)\end{array}$ & $\begin{array}{c}\mathrm{Vp}^{\mathrm{c}} \\
\left(\mathrm{cm}^{3} \mathrm{~g}^{-1}\right)\end{array}$ & $\begin{array}{c}\mathrm{Dp}^{\mathrm{d}} \\
(\mathrm{nm})\end{array}$ \\
\hline $\mathrm{TiO}_{2}$-NS-nc & 9.5 & 260 & 0.26 & 4.1 \\
$\mathrm{TiO}_{2}$-NS-c & 10.5 & 190 & 0.36 & 7.7 \\
$\mathrm{TiO}_{2}$-Tol-nc & 9.0 & 170 & 0.36 & 12.4 \\
$\mathrm{TiO}_{2}$-Tol-c & 10.0 & 120 & 0.39 & 12.1 \\
$\mathrm{TiO}_{2}$-Squ-nc & 10.5 & 160 & 0.34 & 8.3 \\
$\mathrm{TiO}_{2}$-Squ-c & 11.5 & 120 & 0.21 & 7.3 \\
\hline
\end{tabular}

${ }^{a}$ crystallite size estimated by the Scherrer equation from the (101) reflection; ${ }^{b}$ specific surface area; ctotal pore volume at $\mathrm{P} / \mathrm{P}_{0}=0.99 ;{ }^{\mathrm{d}} \mathrm{BJH}$ average pore diameter calculated from the desorption branch.

To complete this study, the electrochemical lithium storage performance of $\mathrm{TiO}_{2}$-Tol-c and $\mathrm{TiO}_{2}$-Squ-c was investigated. The rate performance of both samples were nearly identical (Figure S11a), with capacities ranging from $\approx 150 \mathrm{~mA} \mathrm{~h} \mathrm{~g}^{-1}$ at $0.1 \mathrm{C}$ to $\approx 95 \mathrm{~mA} \mathrm{~h} \mathrm{~g}^{-1}$ at $2 \mathrm{C}$. These values are significantly lower than those found for $\mathrm{TiO}_{2}$-NS-c $\left(238\right.$ and $\left.152 \mathrm{~mA} \mathrm{~h} \mathrm{~g}^{-1}\right)$ and only marginally better than those of $\mathrm{TiO}_{2}$-Comm. Comparison of the discharge profiles in Figures $6 \mathrm{~b}$ and $\mathrm{S} 11 \mathrm{~b}$ revealed that the lower capacity of $\mathrm{TiO}_{2}$-Tol-c and $\mathrm{TiO}_{2}$-Squ-c over $\mathrm{TiO}_{2}$-NS-c arises largely from their lower specific surface area. Indeed, the specific capacity arising from reversible surface lithium storage in Region III can be

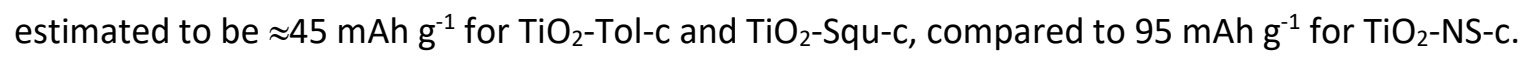

\section{Conclusions}

The reaction of $\mathrm{Ti}\left(\mathrm{O}^{\mathrm{P} P r}\right)_{4}$ with acetic anhydride at $200^{\circ} \mathrm{C}$ provides an efficient, truly non-hydrolytic and aprotic route leading to highly condensed nanocrystalline $\mathrm{TiO}_{2}$ materials. Using acetic anhydride as an oxygen donor allows the in situ formation of intermediate acetoxy groups which further condense with alkoxide groups. The $\mathrm{TiO}_{2}$ nanocrystalline materials prepared in the absence of solvent by this halideand template-free method exhibited very high specific surface areas and high electrochemical lithium storage performances. The presence of residual acetate groups in the non-calcined samples did not hamper electrochemical cycling. Synthesis in the presence of a solvent allows tuning the morphology of the materials, leading to mesoporous samples with lower specific surface area and electrochemical performances. This ester elimination route avoids the use of metal acetate precursors and should be easily extended to other metal oxide systems.

\section{Experimental Section}

\section{Materials}

All manipulations were carried out in a glovebox under argon atmosphere ( $<10 \mathrm{ppm}$ of water and $\mathrm{O}_{2}$ ). Titanium (IV) isopropoxide $\left(\mathrm{Ti}\left(\mathrm{O}^{\mathrm{P} P r}\right)_{4}, 97 \%\right)$ and acetic anhydride $\left(\mathrm{Ac}_{2} \mathrm{O}, 99 \%\right)$ were obtained from Sigma-Aldrich and were used without further purification. Squalane (98\%) was purchased from Alfa Aesar. Commercial titanium oxide nanoparticles (labeled $\mathrm{TiO}_{2}$-Comm in the following) were purchased from Tronox (AK-1, anatase, $\mathrm{S}_{\mathrm{BET}}=85 \mathrm{~m}^{2} \mathrm{~g}^{-1}$, average crystallite size $17.5 \mathrm{~nm}$ ). Toluene (Sigma-Aldrich, 
99.7\%) was dried over a PureSolve MD5 solvent purification system $\left(\mathrm{H}_{2} \mathrm{O}<10 \mathrm{ppm}\right.$, controlled with a Karl Fischer coulometer).

\section{Synthesis of $\mathrm{TiO}_{2}$ materials}

$\mathrm{Ti}\left(\mathrm{O}^{\mathrm{P} P r}\right)_{4},(3.41 \mathrm{~g}, 12.0 \mathrm{mmol})$ and $\mathrm{Ac}_{2} \mathrm{O},(2.45 \mathrm{~g}, 24.0 \mathrm{mmol})$ were mixed in a stainless steel digestion vessel equipped with a PTFE lining $(23 \mathrm{~mL})$. Then the sealed autoclave was heated in an oven at $200^{\circ} \mathrm{C}$ for $12 \mathrm{~h}$ under autogenous pressure. After reaction, the resulting white precipitate was washed with acetone ( $30 \mathrm{~mL}, 5$ times). The precipitate was dried under vacuum at room temperature and then ground into a fine white powder. Calcination of selected samples was carried out at $380^{\circ} \mathrm{C}$ (heating rate $5{ }^{\circ} \mathrm{C} / \mathrm{min}$ ) for $5 \mathrm{~h}$ in dry air (flow rate of $50 \mathrm{~mL} / \mathrm{min}$ ). The non-calcined sample is referred to as $\mathrm{TiO}_{2}$-NS-nc, the calcined one as $\mathrm{TiO}_{2}$-NS-c, where NS stands for 'no solvent'. Two samples were prepared using the same procedure but with addition of $10 \mathrm{~mL}$ of a solvent. The samples prepared in toluene are referred to as $\mathrm{TiO}_{2}$ - Tol-nc (or c) and those prepared in squalane as $\mathrm{TiO}_{2}$-Squ-nc (or c).

\section{Materials characterization}

Fourier-transform infrared (FTIR) spectra were collected in ATR mode on a Spectrum II Perkin-Elmer spectrometer. The powder X-ray diffraction (XRD) patterns were collected with a PANalytical X'Pert Pro MPD diffractometer $(C U K \alpha 1=0.1540598 \mathrm{~nm}$ ). The scanning electron microscopy (SEM) images were obtained with a Hitachi S-4800 electron microscope. The low- and high-resolution transmission electron microscopy (TEM) images were obtained using a JEOL JEM-ARM 200F transmission electron microscope. Nitrogen adsorption and desorption isotherms were measured at $77 \mathrm{~K}$ with a Micrometrics Triflex apparatus; the specific surface area was determined by the BET method, pore size distribution by the BJH method from the desorption branch or by DFT assuming cylindrical pore geometry. ${ }^{1} \mathrm{H}$ and ${ }^{13} \mathrm{C}$ NMR spectra in solution were recorded using a Bruker AVANCE $400 \mathrm{MHz}$ spectrometer. Solid state ${ }^{13} \mathrm{C}$ CPMAS NMR spectra were recorded on a VARIAN VNMRS $300 \mathrm{MHz}$ spectrometer using a $3.2 \mathrm{~mm}$ T3 2 channels probe. Rotors were spun at $12 \mathrm{kHz}$.

\section{Electrochemical characterization}

Galvanostatic electrochemical characterizations were performed at room temperature on a BTS3000 instrument from Neware Battery. $\mathrm{TiO}_{2}$ electrodes were composed of the active material ( $80 \mathrm{wt} \%$ ), Super P (14 wt\%), and sodium carboxymethyl cellulose (CMC, $6 \mathrm{wt} \%)$. After stirring in water, the slurry was ball-milled in a Pulverisette 7 Planetary Micro Mill from Fritsch using an agate grinding jar $(1 \mathrm{~h}$ at $500 \mathrm{rpm})$, then tape casted uniformly at $150 \mu \mathrm{m}$ onto a copper current collector $(0.018 \mathrm{~mm},>99.96 \%$, Prometor) using a 3540 bird film applicator from Elcometer. Electrodes (diameter $12.7 \mathrm{~mm}$ ) were cut with a disk cutter and then dried under vacuum at $80^{\circ} \mathrm{C}$ for $15 \mathrm{~h}$. The loading weight of active material was $\approx 1.5 \mathrm{mg} \mathrm{cm}^{-2}$. CR2032 coin-type cells were assembled in a glove box under $\operatorname{Ar}$ atmosphere $\left(\mathrm{O}_{2}\right.$ $<0.5 \mathrm{ppm}, \mathrm{H}_{2} \mathrm{O}<0.5 \mathrm{ppm}$ ), using lithium metal as both reference and counter electrode. The electrolyte was LP30 (1 M LiPF 6 in ethylene carbonate and dimethyl carbonate in a 1:1 vol. ratio. A glass fiber separator (Whatman) was used. The electrochemical galvanostatic measurements were taken in the voltage range of $2.5-1.2 \mathrm{~V}$ versus $\mathrm{Li}^{+} / \mathrm{Li}$ at different current densities. Cyclic voltammetry (CV) measurements were carried out on a VSP-300 instrument with sweep rate of $0.2 \mathrm{mV} \mathrm{s}^{-1}$ to $10 \mathrm{mV} \mathrm{s}^{-1}$. Electrochemical impedance spectroscopy (EIS) studies were performed on a VSP-300 instrument, from $100 \mathrm{kHz}$ to $20 \mathrm{mHz}$, with a $10 \mathrm{mV}$ amplitude. 


\section{Acknowledgements}

The authors acknowledge the Agence Nationale pour la Recherche (project ANR-16-CE08-0015 SYNCOPE) and the European Commission (POROUS4APP project GA no. 666157), the University of Montpellier and CNRS for financial support.

\section{Conflicts of interest}

The authors declare no conflict of interest.

Keywords: non-hydrolytic sol-gel . acetic anhydride route . anatase . mesoporous . Li-ion batteries

[1] X. Chen, S. S. Mao, Chem. Rev. 2007, 107, 2891-2959.

[2] T. L. Thompson, J. T. Yates, Chem. Rev. 2006, 106, 4428-4453.

[3] M. Wagemaker, W. J. H. Borghols, F. M. Mulder, J. Am. Chem. Soc. 2007, 129, 4323-4327.

[4] T. Song, U. Paik, J. Mater. Chem. A. 2016, 4, 14-31.

[5] J.-Y. Shin, D. Samuelis, J. Maier, Adv. Funct. Mater. 2011, 21, 3464-3472.

[6] A. Vioux, Chem. Mater. 1997, 9, 2292-2299.

[7] M. Niederberger, Acc. Chem. Res. 2007, 40, 793-800.

[8] N. Pinna, M. Niederberger, Angew. Chem. Int. Ed. 2008, 47, 5292-5304.

[9] P. H. Mutin, A. Vioux, Chem. Mater. 2009, 21, 582-596.

[10] A. Styskalik, D. Skoda, C. Barnes, J. Pinkas, Catalysts. 2017, 7, 168.

[11] R. Deshmukh, M. Niederberger, Chem. - Eur. J. 2017, 23, 8542-8570.

[12] M. Niederberger, M. H. Bartl, G. D. Stucky, Chem. Mater. 2002, 14, 4364-4370.

[13] G. Garnweitner, M. Niederberger, J. Am. Ceram. Soc. 2006, 89, 1801-1808.

[14] M. Niederberger, G. Garnweitner, J. Ba, J. Polleux, N. Pinna, Int. J. Nanotechnol. 2007, 4, 263281.

[15] T. J. Trentler, T. E. Denler, J. F. Bertone, A. Agrawal, V. L. Colvin, J. Am. Chem. Soc. 1999, 121, 1613-1614.

[16] J. Joo, T. Yu, Y. W. Kim, H. M. Park, F. Wu, J. Z. Zhang, T. Hyeon, J. Am. Chem. Soc. 2003, 125, 6553-6557.

[17] A. Aboulaich, O. Lorret, B. Boury, P. H. Mutin, Chem. Mater. 2009, 21, 2577-2579.

[18] A. Aboulaich, B. Boury, P. H. Mutin, Chem. Mater. 2010, 22, 4519-4521.

[19] P. H. Mutin, A. Vioux, J. Mater. Chem. A. 2013, 1, 11504-11512.

[20] D. P. Debecker, V. Hulea, P. H. Mutin, Appl. Catal., A. 2013, 451, 192-206.

[21] M. Jansen, E. Guenther, Chem. Mater. 1995, 7, 2110-2114.

[22] U.-Y. Hwang, H.-S. Park, K.-K. Koo, Ind. Eng. Chem. Res. 2004, 43, 728-734.

[23] J. Joo, S. G. Kwon, T. Yu, M. Cho, J. Lee, J. Yoon, T. Hyeon, J. Phys. Chem. B. 2005, 109, 1529715302.

[24] K. Bernal Ramos, G. Clavel, C. Marichy, W. Cabrera, N. Pinna, Y. J. Chabal, Chem. Mater. 2013, 25, 1706-1712.

[25] E. Rauwel, G. Clavel, M.-G. Willinger, P. Rauwel, N. Pinna, Angew. Chem., Int. Ed. 2008, 47, 3592-3595.

[26] P. Arnal, R. J. P. Corriu, D. Leclercq, P. H. Mutin, A. Vioux, J. Mater. Chem. 1996, 6, 1925-1932.

[27] G. Guo, J. K. Whitesell, M. A. Fox, J. Phys. Chem. B. 2005, 109, 18781-18785.

[28] K.-H. Ahn, Y.-B. Park, D.-W. Park, Surf. Coat. Technol. 2003, 171, 198-204.

[29] M. Thommes, K. Kaneko, V. Neimark Alexander, P. Olivier James, F. Rodriguez-Reinoso, J. Rouquerol, S. W. Sing Kenneth, Pure Appl. Chem. 2015, 87, 1051-1069.

[30] Y.-G. Guo, Y.-S. Hu, J. Maier, Chem. Commun. 2006, 2783-2785.

[31] T. Froschl, U. Hormann, P. Kubiak, G. Kucerova, M. Pfanzelt, C. K. Weiss, R. J. Behm, N. Husing, U. Kaiser, K. Landfester, M. Wohlfahrt-Mehrens, Chem. Soc. Rev. 2012, 41, 5313-5360. 
[32] R. Rossmanith, C. K. Weiss, J. Geserick, N. Hüsing, U. Hörmann, U. Kaiser, K. Landfester, Chem. Mater. 2008, 20, 5768-5780.

[33] S. O. Baumann, M. J. Elser, M. Auer, J. Bernardi, N. Hüsing, O. Diwald, Langmuir. 2011, 27, 1946-1953.

[34] Z. Xiu, M. H. Alfaruqi, J. Gim, J. Song, S. Kim, P. T. Duong, J. P. Baboo, V. Mathew, J. Kim, J. Alloys Compd. 2016, 674, 174-178.

[35] J. Wang, Y. Zhou, Y. Hu, R. O'Hayre, Z. Shao, J. Phys. Chem., C. 2011, 115, 2529-2536.

[36] G. Sudant, E. Baudrin, D. Larcher, J.-M. Tarascon, J. Mater. Chem. 2005, 15, 1263-1269.

[37] M.-x. Jing, J.-q. Li, C. Han, S.-s. Yao, J. Zhang, H.-a. Zhai, L.-I. Chen, X.-q. Shen, K.-s. Xiao, Royal Society Open Science. 2017, 4.

[38] J. Wang, J. Polleux, J. Lim, B. Dunn, J. Phys. Chem. C. 2007, 111, 14925-14931.

[39] Y. Wang, Y. Song, Y. Xia, Chem. Soc. Rev. 2016, 45, 5925-5950.

[40] T. Brezesinski, J. Wang, S. H. Tolbert, B. Dunn, Nature Materials. 2010, 9, 146.

[41] L. R. F. A.J. Bard, Electrochemical Methods: Fundamentals and Applications, John Wiley \& Sons, Inc., 2000.

[42] J. Liu, J. Luo, W. Yang, Y. Wang, L. Zhu, Y. Xu, Y. Tang, Y. Hu, C. Wang, Y. Chen, W. Shi, J. Mater. Sci. Techno. 2015, 31, 106-109.

[43] R. L. Penn, J. F. Banfield, Geochim. Cosmochim. Acta. 1999, 63, 15491557.

\section{Table-of-Contents}

Ester elimination non-hydrolytic sol-gel route revisited. The reaction of $\mathrm{Ti}\left(\mathrm{O}^{\mathrm{i}} \mathrm{Pr}\right)_{4}$ with acetic anhydride at $200{ }^{\circ} \mathrm{C}$ leads to mesoporous nanocrystalline $\mathrm{TiO}_{2}$ with a hierarchical porosity and a very high specific surface area. This truly non-hydrolytic sol-gel route involves the intermediate formation of Ti-OAc groups which then condense with Ti-O'Pr groups along with ester elimination. Evaluation of lithium storage performances shows a high reversible specific capacity, good cyclability and coulombic efficiency.

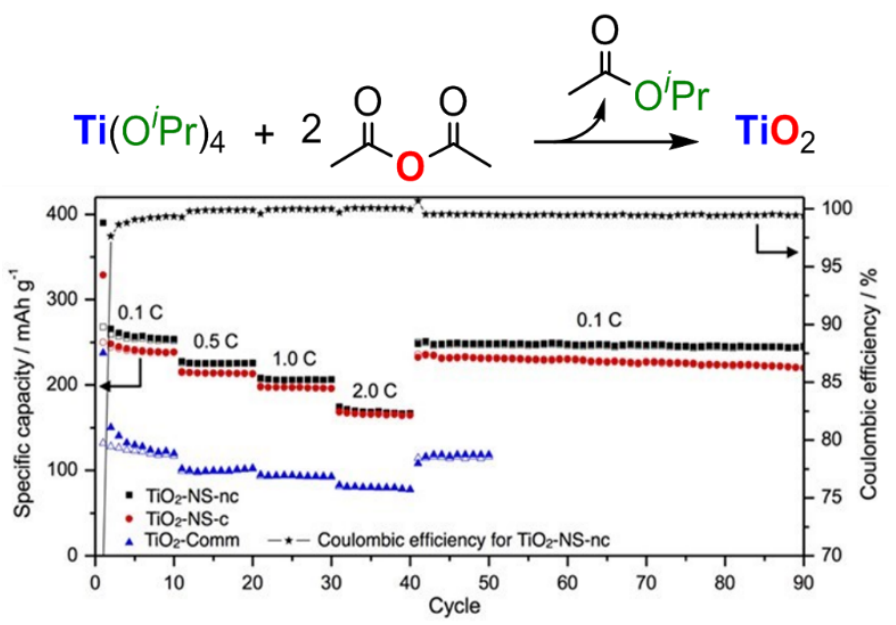

